\title{
Bank Rakyat Indonesia's Mobile Banking Services Customers in Jember Sub-Branch Office
}

\author{
Tsiqoh Billah \\ Master Program Students of Administrative Science, \\ Faculty of Social and Political Sciences, University of Jember, Indonesia \\ Akhmad Toha \\ Lecturer of Business Administration, \\ Faculty of Socialand Political Sciences, University of Jember, Indonesia \\ Zarah Puspitaningtyas \\ Lecturer of Business Administration, \\ Faculty of Social and Political Sciences, University of Jember, Indonesia
}

\begin{abstract}
This study is a qualitative study aimed at explaining the analysis of Bank Rakyat Indonesia's mobile banking (m-Banking) services at the Jember Sub-Branch Office and to find out BRI's strategy in improving m-Banking services as a reliable product for customers. The progress of the business system with the e-commerce system makes consumers switch ways by using non-cash payment methods (cashless). Technological advancements in the banking sector have encouraged the banking sector to be more innovative in providing non-cash payment services in the form of a transfer system and payment instruments in the form of electronic cards, because they are secure, fast, efficient, and global. The study found that there are obstacles, namely an easy network error so that transactions can be hampered, high SMS costs for business people, can be easily accessed by others if customers forget to log off. The conclusions of using the TASS (Trust, Accuracy, Speed, Scurity) method from these five aspects are security and speed that need to be considered by the BRI Bank, because there are several cases of cyber crime and old repairs / maintenance.
\end{abstract}

Keywords: E-commerce, m-Banking, Service Characteristics, Service Quality, Banking Services.

\section{INTRODUCTION}

Internet is one of the valuable invention for humanity because with Internet someone could gain information they need, and someone could communicate with internet regardless of distances. Internet access has become easier, any kind of information could spread rapidly even to the point that they're hard to control (Agus, 2005). The advancement of information technology especially the Internet media has been known to have so many advantages in many areas such as security, comfort and speed. 
Today's e-commerce is used by using the internet that reachable through a computer, this capability has been utilized by businesses gathering information by using a computer which started by giving information to their potential customers with corresponding choices. The Banking acknowledge this potential which are getting more dynamic in the e-commerce area, enabling the internet users to use it in their financial transaction. For how it has been seen as the numbers of banks increasing in competing for the higher value that they could give to their customers through specialized to their needs and wants. Phenomenon like this can be seen as mobile banking services introduced by banking companies (Kurniawan, 2013). Electronic banking or m-Banking also defined as a form of a bank service directly to the customer through electronics, m-Banking networks covers the system for individual or companies to access their own account, business transaction, or other information even interesting products promos and services by using their own private network through the internet.

M-Banking is one of e-banking services to the customers through electronics, interactive communication network. E-banking covers a system that enables bank costumers, either individual or business to access their account, doing business transaction, or to get product information and bank services by using private network or public through the internet whereas its products are formed as internet banking, mobile banking which is handphone based service, ATM (Automatic Teller Machine), Credit Card and among other things.

Bank Rakyat Indonesia (BRI) becomes one of the service providers of m-Banking with a vision to become an upfront commercial bank who always put its first interest in customers satisfaction and one the missions is to give a prime service to the customers through wide working network areas and supported by professional human resources. BRI Mobile is a feature of BRI service in giving services to the customers. M-Banking feature use online facility or by using mobile phone, tablets and other type pf communication devices. BRI Mobile has its form as an app which integrates eBanking services that have consisted of Mobile Banking, Internet Banking, T-Bank, Brizzi and have additional menus namely BRI Info and Call BRI, all of these features can be accessed by using a smartphone. Till this day and age, mobile banking users reached a number of 12 millions users which surpassed its original target for only 10 million users (Sandy, 2015) with total transactions reached up to Rp 62 trillions (Kusuma, 2015). Moreover, the other side of m-Banking service owns their own obstacles for the customers. The obstacles that the customers has been experienced with are how easily PIN numbers get blocked if the customers repeatedly inserting the wrong PIN, networks error too often that hampered their transaction process, high SMS price for businesses , information are less private and easy to access by other people without the account holder permission if they forgot to log off, for some brand of mobile phones turns out that m-Banking application needs specialized tune in the setting part that complicates its users and updates are coming too often which messed transactions system and made the user id couldn't be accessed. Among mentioned obstacles above there other obstacles that are faced by customers who have less knowledge regarding to how to use this relatively new technology which resulting in difficulties upon accessing mobile banking, the customers who didn't have email address. The already existed limitation still less secure for big businesses which hammered their account to account transfer system. Thus it becomes an irony because BRI itself can be seen as a big commercial bank. 
Billah, T., Toha, A., \& Puspitaningtyas, Z. (2020) Bank Rakyat Indonesia's Mobile Banking Services Customers in Jember Sub-Branch Office. Archives of Business Research, 8(4). 146-154.

\section{Administration Theory in Banking}

\section{LITERATURE REVIEW}

Administration as a science can be studied and taught openly so that it continues to grow until now. The term epistemological administration comes from the Latin (Greek) which consists of two words namely "ad" and "ministrate" which means "to serve" which in Indonesian means to serve or fulfill. Another opinion quoted from A. DunsireKeban (2008), administration is defined as direction, governance, implementation activities, directing activities, creating principles of public policy implementation, activities to analyze, balance and present decisions, as individual and group work in producing goods and services public, and as an arena of academic and theoretical work fields. Administration in the narrow sense is an activity that includes notes, correspondence, light bookkeeping, typing, agenda, etc. that have the technical nature of administration, while the notion of administration is broad is the whole process of cooperation of two or more people in achieve its objectives by utilizing certain facilities and infrastructure in an efficient and effective manner. Overall administration that occurs in JCP BRI KCP is a process of cooperation between bank employees and their customers. Aiming that the use of $\mathrm{m}$-Banking technology can work as expected by customers. The recent information technology (IT) advancement is very rapid, so that the banks, especially BRI KCP Jember provides counseling to its customers to maximize the use of m-Bankings in order to facilitate the financial transaction activities of its customers.

\section{The Role of Technology Information in Banking World}

The development of information technology has made companies change their business strategies by placing technology as a major element in the process of product and service innovation. Electronic banking services (e-banking), for example through ATMs, phone banking and Internet Banking, are new forms of bank services that convert manual transaction services into technologybased transaction services. The purpose of E-banking is as a multi-channel provider and can also save bank transaction fees, customers are more free, easy, fast and secure 24-hour transactions wherever the customer is while connected to the internet network. According (Alghifari, 2015), Information technology has colored the banking world, the presence of online systems handled by computer technology and communication technology enables customers to take money from bank branches anywhere. This system is equipped with Automatic Teller Machine machines, hereinafter referred to as ATMs.

The definition of mobile banking itself is a facility of banks in this modern era that follows the development of technology and communication. The services contained in m-Banking include payments, transfers, history, etc. The use of m-Banking services on cellular phones allows customers to more easily carry out their banking activities without space and time limits. The existence of the $\mathrm{m}$-Banking service is expected to provide convenience and benefits for customers in accessing the bank without having to come directly to the bank (Hanif, et al. 2017). M-Banking is an innovative service offered by banks that allows users of banking transaction activities via smartphones.

The benefits of m-banking have its own advantages felt by both the customer and the bank itself, among others: Mobile banking is a service provided by banks to conduct various banking transactions through various features available on smartphones. At a glance this mobile banking service is similar to sms banking services, but in reality mobile banking has more features compared to sms banking. Mobile banking offers a variety of services for customers, ranging from 
checking account balances, payment history, transfers to other accounts and others and all via cellphone. There is no need for customers to come to the bank to conduct banking activities except when registering and withdrawing cash. Using a cellphone the customer can reach the bank and conduct banking activities anywhere and anytime that is accessed by the internet network. For security issues, all banking transactions carried out by customers are encrypted / encrypted to ensure the security of these transactions, and the benefits for banks are increased productivity, reduced costs and labor and increased profits, the bank that first implements IT will benefit from the appearance of having a brand that more competitive and greater market share (Salehi and Alipour, 2010).

\section{Services Quality}

Quality of service is a necessity that must be done by the company in order to be able to survive and still get the trust of customers. Consumption patterns and customer lifestyles require companies to be able to provide quality services. The company's success in providing quality services can be determined by the Trust, Accuracy, Speed, Security (TASS) approach developed (Gummeson and Lovelock, 2004). Service quality is a measure of how well a service meets the expectations of the customer. Implementing service quality means making compromises with the expectations of customers (customers) with consistent procedures in a service company. The TASS method is a method used to measure service quality from the attributes of each dimension, so that a gap value is obtained which is the difference between consumers' perceptions of services that have been received with expectations of what will be received. This method is measured by measuring the quality of service from the attributes of each dimension, so that a gap value will be obtained which is the difference between consumers 'perceptions of services received with consumers' expectations of services to be received.

\section{The Dimensions of Services}

Trust, which is the customer's trust in the bank where BRI's m-banking services are conducted. Each layer of employees from top / high management level (top management) to the lowest level (staff) is seen to provide the best service to consumers. Appearance of physical facilities, equipment, technology and various communication materials presented by BRI is good, interesting and well maintained. Accuracy, the speed and accuracy in obtaining information about m-banking. BRI's ability to provide services in accordance with what was promised, trusted, accurate, and consistent and gives its customers satisfaction. Speed, which is the speed and convenience of customers in conducting m-Banking services. The willingness of all BRI residents to help customers and provide services quickly and to hear and resolve complaints from consumers is good, it's just that in some instances BRI has been seen to be swift, for example long and protracted maintenance. Security, namely the guarantee of confidentiality in every m-Banking service. BRI's ability to generate confidence and trust in promises made to consumers is already good with the right questions and an accurate explanation of the mechanism and procedure of a transaction before the customer does so. In the field, it was discovered that there was a different phenomenon that this m-Banking service needed education both in the form of socialization to customers to BRI employees. The quality of service from Parasurahman in Rianto (2010) on the TERRA scale (Tangibles, Empathy, Reability, Responsiveness, Assurance) is needed by Empathy primarily in the Jember community. Empathy which has components: giving attention (Education) to prospective customers / customers, employees treat customers attentively, employees understand customer needs This method has five factors determining the quality of service abbreviated as TASS (Trust, 
Billah, T., Toha, A., \& Puspitaningtyas, Z. (2020) Bank Rakyat Indonesia's Mobile Banking Services Customers in Jember Sub-Branch Office. Archives of Business Research, 8(4). 146-154.

Accuracy, Speed, Security) fromGummeson and Lovelock (2004) by merging only Education that occurs in the field, namely BRI KCP Jember customers from the TERRA component (Tangible, Emphaty, Reability, Responsiveness, Assurance), which is abbreviated to TASSE (Trust, Accuracy, Speed, Scurity, Education).

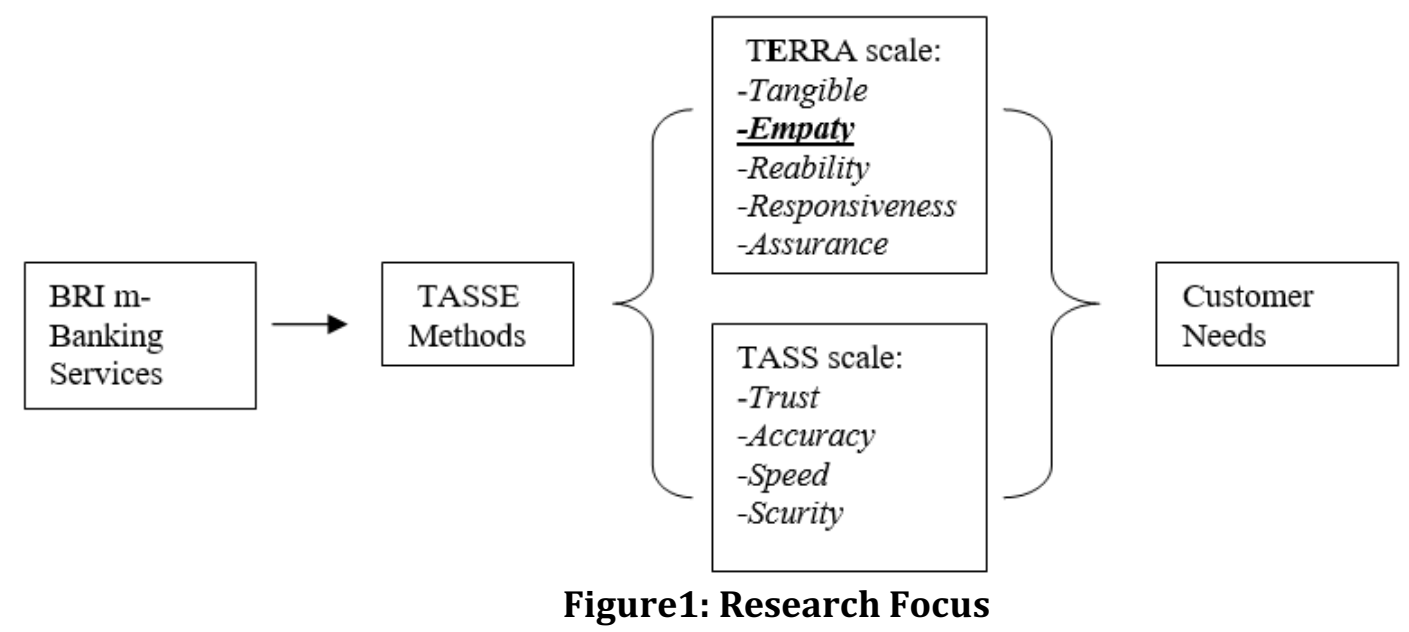

Source : Processed Data/Researched Data

\section{RESEARCH METHOD}

Research that is then associated with the problem to be studied, the research paradigm that will be used in this research is descriptive research with a qualitative approach. The qualitative research process encompasses the six main steps that begin with ideas, literature reviews, then design research, data collection, analysis and findings and dissemination of research results. The validity of the data in this study was tested using persistence of observations, source triangulation, and peer examinations.Determination of the informants in this study was done by postposition sampling, where the selection was made deliberately based on predetermined criteria and determined based on the research objectives.

Determination of the informant at the KCP BRI Jember City researchers determine 2 key informants, namely as follows:

1. Informant for Operational Services

a. Name: Mrs. RastiNurwulandari

b. Position: BRI KCP Services Supervisor

2. Informant for Customer Service

a. Name: AnggaFirmansyah

b. Position: Junior Customer Service

Key informant $A$ is the supervisor who controls customer service and checks the data of $m$-Banking customers who register for the first time and old customers. Key B informant is customer service registering through the system for customers and educating the use of m-banking.

Data collection techniques according to Wiratna (2010) in this research are literature studies, observational studies, interview studies, documentation studies. In this study using data analysis methods, namely interactive analysis. Interactive analysis is a qualitative data analysis model made 
by Miles and Huberman (2014). This analysis model consists of four activities and these are the paths that researchers use in compiling research reports, namely: Data Collection (Data Collection), Data Condensation, Data Display, Conclusion Drawing / Verifying or (Verification) or Draw a conclusion.

\section{RESULT AND DISCUSSION}

The banking world is trying to make it easier for customers to access transactions. One of them is the progress of IT with the presence of Mobile Banking or M-Banking. Banking services through communication devices (mobile phones) are quite practical in their use. As the name implies it is truly mobile and can be used anywhere and anytime, as long as it is connected to an operator / internet network. Customers no longer need to go to an ATM / Branch Office to conduct transactions. This aspect received attention in order to maintain the quality of BRI's m-Banking services to its customers, namely the determinants of the quality of BRI's m-Banking services, abbreviated as TASSE (Trust, Accuracy, Speed, Security, Education) that occur in the field.

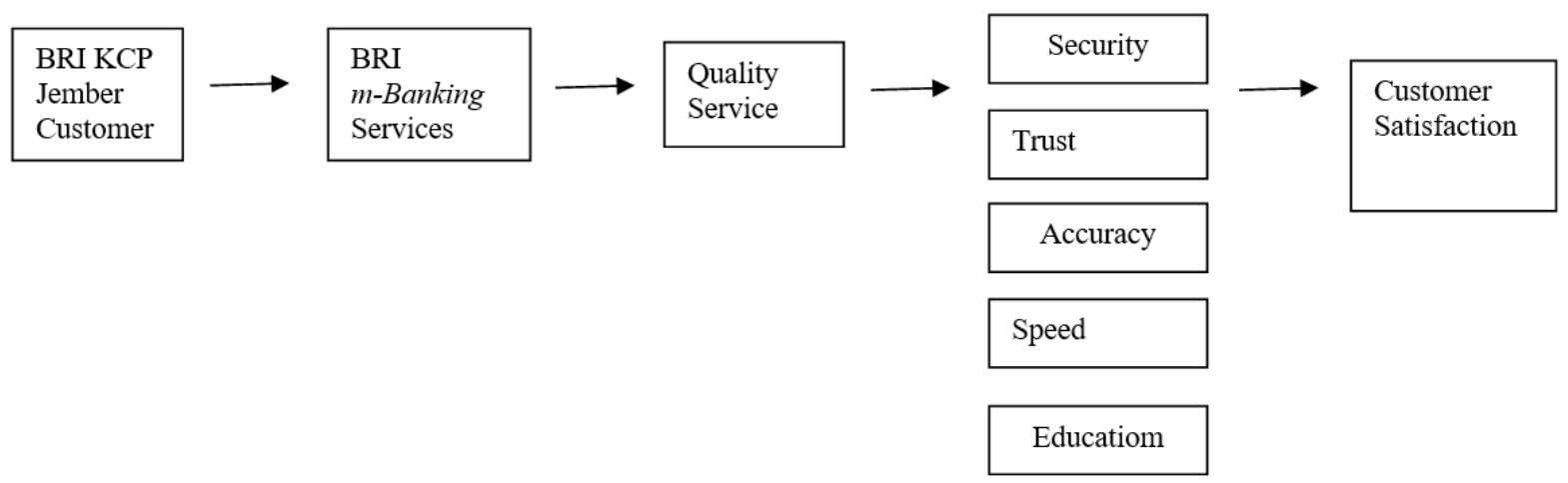

Figure 2: Research Chart of m-Banking BRI KCP Jember

Source: Processed Data/Researched Data

The existence of digital services in the form of m-Banking is expected to be able to optimize BRI services to customers by facilitating transactions. To support this digital banking service, BRI has provided easy access to contact BRI regarding complaints or product information, promos, features, and other facilities. The activity was carried out by interviewing BRI customers and employees about the BRI KCP m-Banking service in Jember City. BRI's m-Banking service is good and really helps customers in conducting banking transactions. Because the registration procedure is relatively easy but still pay attention to the security element. It has becoming a positive value from BRI's m-Banking is because it has a relatively complete facility, so customers have many variants in determining the type of transaction. In accordance with the opinion of Lupiyoadi (2006) which states that service must start from customer needs and end on customer perception. Because a good quality image is not seen from the perception of the provider, but based on customer perception. Customer perception of service quality is a comprehensive assessment of the superiority of a product. Demand related parties (BRI) to accelerate repairs if there are those that are considered lacking while simultaneously providing a good understanding of the problems that are happening to customers. There are several aspects of TASSE that received attention in the context of BRI's m-Banking service quality, namely: 
Billah, T., Toha, A., \& Puspitaningtyas, Z. (2020) Bank Rakyat Indonesia's Mobile Banking Services Customers in Jember Sub-Branch Office. Archives of Business Research, 8(4). 146-154.

1. Security is one aspect of bank and customer attention. Security is an important factor that must be considered in the m-Banking service. The security guarantee provided by the BRI fosters trust and results in attracting customers to use m-Banking. The case about security that is happening right now is that Phishing is a criminal activity using social engineering techniques. Phishers (a term for phishing criminals) attempt to cheat to get sensitive information, such as usernames, passwords and credit card details by posing as a trusted entity in an electronic communication. The security system is an important evaluation material for BRI in an effort to improve quality and comfort for customers. Security is one of the reasons that most often arises when a customer uses mobile banking. The existence of a sense of security is a basic requirement that is needed by customers when conducting financial transactions and is protected by secrecy by banking laws making customers motivated to use m-Banking services because of the security principle followed by the features and notifications contained in the mBanking service.

2. The speed of service in the communication technology revolution and information technology resulted in extraordinary changes in the business world, including the banking business. The customer wants a comfort, efficiency, and fast and accurate answers to all transactions. The role of technology in the banking world is absolutely absolute, where progress a banking system is certainly supported by the role of information technology. The development of e-Channel experienced a big leap, bank transactions became fast, easy and real time without any time and place restrictions. The reliability of BRI employees to help customers and provide fast and responsive services, which include alertness in serving customers, speed in handling transactions, and handling customer complaints. BRI's non-cash transactions are a popular alternative to address the challenges of today's transactions that need to be fast, practical and safe.

3. Accuracy in transactions and information is very important to customers, especially for business customers. Financial transactions include transfers, purchases, and payments, while non-financial transactions include balance checks and account mutation checks. The account mutation itself is a record containing transaction details on an account. The customers, the account mutation is useful to know and control each transaction, help smooth transactions, and maintain account security. These control account movements are also a safety indicator for transactions that may be carried out by other parties who are not responsible for the customer's account. Customers can also check account transfers by SMS only. A customer believes that this service still has limitations in displaying account mutation services or checking accounts. Customers who have large businesses are very difficult to track some odd transactions that occurred a few months ago. The informant provided input on the account mutation services found in BRI m-Banking.

4. Trust develops into a fundamental component of a marketing strategy shown to lead to the creation of customer relationships. Trust develops after individuals take risks in dealing with their partners. Trust is needed by technology users in order to improve individual performance in carrying out the activities of an organization or company. Very fierce product quality competition will have an impact on customer trust, so marketing is needed so that companies can develop rapidly. The ability of good service products will have an impact on the wearer and 
will strengthen or be able to get the best position to gain customer loyalty, so service is very important for the company.

5. Banking education or also known as knowledge is all planned efforts to influence other people both individuals, groups, or the public so that they do what is expected by the banking actors. The development of banking technology is expected to change the banking system in the eyes of the Indonesian people who initially put the bank only to save money into e-Commerce business transactions. Along with the development of these technologies the use of education is needed between the two parties, namely bank employees and their customers. BRI KCP City of Jember continues to educate m-Banking services to realize the minimum possible cash transactions and intensify non-cash transactions due to the benefits provided by the non-cash transactions. BRI also educates customers about BRI's m-Banking services along with their practical and simple features that are easily understood. customers and to meet their needs. The development of the m-banking service is expected to accelerate service to customers and improve service quality when making transactions at BRI.

The five aspects mentioned above are chain of series that cannot be separated so they must be fulfilled in an effort to improve the quality of m-Banking services, it is hoped that the queues that are too long in the Banking Hall can be decomposed bit by bit, as well as movements that are promoted in the form of cashless (non-cash) through the media m-Banking can run in the wider community, especially among BRI customers themselves. The development of e-commerce business penetrated to all sides of modern human life today that utilize things that smell of the economy. The sophistication of internet technology really helps humans in meeting their needs so that these five aspects are interrelated.

Of the five aspects, security and speed of service need to be considered by BRI Bank, because there are several cases of cyber crime and repair / maintenance services that require a long time and various actual needs that have not been covered in BRI's m-banking services. Crimes are increasingly developing in the world of technology often the development of IT, as well as the speed of service in knowing information about each customer's account is a priority that is considered by the bank. A bad network from both the provider and the bank service maintenance makes many complaints felt by customers. Regarding security in using m-Banking. Customers are always given education from the beginning of the registration until the customer experiences difficulties / obstacles. The customer plays an active role in monitoring the security offered by BRI, by changing the passcode / password regularly. Passwords are important for security. Mobile customers who have been verified by m-Banking are required to provide multiple layers of security so it is difficult for others to use. Password settings are very important because in all smartphones valuable data and information, including financial matters, are stored in them. Replacement password that is not easily recognized by others and regularly. Updating the mobile banking application installed on the smartphone needs to be done to ensure that the application is equipped with the latest security services. Updating mobile banking application on a regular basis, customers can enjoy the benefits as well as a variety of features (eg enhanced security) is offered in the latest version of the application as well as increased security. 
Billah, T., Toha, A., \& Puspitaningtyas, Z. (2020) Bank Rakyat Indonesia's Mobile Banking Services Customers in Jember Sub-Branch Office. Archives of Business Research, 8(4). 146-154.

\section{CONCLUSION}

Based on the results of research and analysis that researchers have conducted at BRI City SubBranch Office (JalanHayamWuruk), the researcher draws conclusions from the research "Mobile Banking Services (M-Banking) of Bank Rakyat Indonesia Customers at the Jember Sub-Branch Office", that: -Banking BRI is already good in terms of aspects, guaranteed security, reasonably good service speed, ease of use and efficiency provided, accurate service accuracy, and consistent ongoing education. Evaluations that need to be done at all times of the security system and service speed are very much needed to be considered. The security side in the form of crime is increasingly developing in the world of technology, often the development of IT, and the speed of service in knowing information about the accounts of each customer is a priority that is considered by the bank. A bad network from both the provider and the bank service maintenance makes many complaints experienced by customers to access the personal accounts of the customers. Overall, Bank Rakyat Indonesia's customers' Mobile Banking (M-Banking) Services at the Jember SubBranch Office security and speed of service components are needed by customers.

\section{References}

Budi Agus, Riswandi. (2005).Aspek Hukum Internet Banking, Jakarta : Raja Grafindo Persada.

Kurniawan, D., Semuel. H, dan Japarianto. E. (2013). Analisis Penerimaan Nasabah Terhadap Layanan Mobile Banking dengan Menggunakan Pendekatan Technology Acceptance Model dan Theory Of Reasoned Action. Jurnal Strategi Pemasaran.

Sandy, Kunthi Fahmar. (2015). Pengguna Mobile Banking Melebihi Target. https://ekbis.sindonews.com/read/1060558/178/pengguna-mobile-banking-bri-melebihi-target1447199332. access 30 Desember 2017.

Kusuma, Hendra (2015). Transaksi Mobile Banking BRI Tembus Rp62 Triliun. https://economy.okezone.com/read/2015/10/28/457/1239372/transaksi-mobile-banking-bri-tembusrp62-triliun. accses 30 Desember 2017

Keban, Y. (2008). Enam Dimensi Strategi Administrasi Publik, Konsep, Teori, Dan Isu. Cetakan Kedua. Yogyakarta: Gava Media.

Alghifari. (2015). Analisis Regresi Untuk Bisnis dan Ekonomi. Yogyakarta: BPFEYogyakarta.

Hanif, A., Winarno. W,dan Arif. A.(2017). Analisis Minat Penggunaan Mobile Banking Dengan PendekatanTechnology Acceptance Model (TAM) Yang Telah Dimodifikasi(Analysis Behavioral Intention to Uses of Mobile Banking TechnologyAcceptance Model (TAM) Approach Modified).e-JournalEkonomi Bisnis dan Akuntansi. IV (1) : 24-29

Salehi, M., and Alipour, M., . (2010). "E-Banking in Emerging Economy: EmpiricalEvidence of Iran”. International Journal of Economic and finance Vol.2, No.1.

Gummesson, E. andLovelock. C. (2004). Whither Service Marketing. In Search of a New Pradigm and Fresh Perspective.Journal of Service Research, 7 (1). 20-41.

Rianto, N.A.A. (2010).Dasar-Dasar Pemasaran Bank Syariah, Bandung: Alfabeta.

Wiratna.(2014). Metode Penelitian, Yogyakrta: Pustaka Baru Press.

Matthew, M. B. dan Michael. H. (2014).Analisis Data Kualitatif.Jakarta: UI Press.

Lupiyoadi, R.dan A. Hamdani.(2006).Manajemen Pemasaran Jasa. Edisi: kedua. Jakarta: Penerbit Salemba Empat. 